J. Kyushu Dent. Soc. 52 (6) :663 670, 1998.

\title{
Serum Tumor Necrosis Factor $-\alpha$ Level is a Valuable Tumor Marker of Patients with Oral Squamous Cell Carcinoma
}

\author{
Hideo Kurokawa, Yoshihiro Yamashita, Tomoyuki Murata \\ and Minoru Kajiyama \\ Second Department of Oral Surgery (Chief : Prof. Minoru Kajiyama) \\ Kyushu Dental College, Kitakyushu, Japan
}

Key words: Tumor necrosis factor/Oral squamous cell carcinoma/Tumor marker

Accepted on October 26, 1998.

Tumor necrosis factor $-\alpha(\mathrm{TNF}-\alpha)$, a product of activated macrophages, is an important mediator in cytoprotection ${ }^{1)}$. $\mathrm{TNF}-\alpha$ has been reported to have a direct action against cancer cells by the exertion of an antitumor effect through both an indirect mechanism and via the activation of such immunologically competent cells as neutrophils and macrophages ${ }^{2,3)}$. Since the functions of $\mathrm{TNF}-\alpha$ are sophisticated and sometimes produce harmful reactions in the tumor-bearing host, estimates of the serum $\mathrm{TNF}-\alpha$ levels in cancer patients prior to surgery vary greatly ${ }^{4}$. So far there have been few studies on the usefulness of the serum TNF- $\alpha$ levels as a tumor marker for oral squamous cell carcinoma ( $\mathrm{O}-\mathrm{SCC})$. On the other hand, the tumor markers that have been used in patients with oral $\mathrm{O}-\mathrm{SCC}$ include carcinoembryonic antigen $(\mathrm{CEA})^{5,6)}$, squamous cell carcinoma antigen (SCCA $)^{6,7)}$, immunosuppressive acidic protein $(\mathrm{IAP})^{6)}$, gulutathione S-transferase $-\pi(\mathrm{GST}-\pi)^{8)}$, dipeptidyl-peptidase (DPP) ${ }^{9)}$, and fragment of cytokeratin subunit $19(\mathrm{Cyfra})^{10)}$. A combination assay with CEA, SCCA, and IAP has been reported to be especially useful for the screening of patients with $\mathrm{O}-\mathrm{SCC}^{11}$. In order to estimate the presurgery serum $\mathrm{TNF}-\alpha$ levels as a means of performing both diagnosis and postoperative prognosis, we thus examined the serum $\mathrm{TNF}-\alpha$ levels. In addition, we investigated the relationships among the serum $\mathrm{TNF}-\alpha$ levels and these tumor markers.

\section{Patients and Methods}

Thirty-eight consecutive patients with $\mathrm{O}-\mathrm{SCC}$, who were treated in our department between 1989 to 1992 , were entered into this study. The patients ranged in age from 34 to 89 years; 23 of them were men and 15 women. The anatomic sites of $\mathrm{O}-\mathrm{SCC}$ included the tongue (15), mandibular gingiva (11), maxillary gingiva (9), the floor of the mouth (2), and buccal mucosa (1). Eight patients demonstrated Stage I disease, 9 had Stage II disease, 8 had Stage III disease, and 13 had Stage IV disease according to the UICC staging system ${ }^{12}$. The patients were separated into two groups after treatment. The good-prognosis group consisted of 16 patients who remained completely free from cancer for more than 5 years after the primary treatment. The poor-prognosis group comprised 22 patients who all died 
due to local recurrence at the primary site because of either regional lymph node metastasis or distant metastasis.

Blood specimens were collected after informed consent was obtained. The sera were centrifuged for 20 minutes at $2000 \mathrm{~g}$, and then stored at $-80{ }^{\circ} \mathrm{C}$ until analysis. The control group comprised 26 normal individuals (healthy clinical personnel). The serum TNF- $\alpha$ levels were measured with an enzyme-linked immunosorbent assay (ELISA) using a highly sensitive TNF assay kit (Tore Fuji Bionics, Tokyo, Japan). One monoclonal antibody was immobilized in each well of a 96-well microplate. After the plates were washed with phosphate-buffered saline (PBS), $200 \mu \mathrm{l}$ of standard and test samples were allowed to react with this antibody and were incubated for 2 hours at room temperature. After 3 washes, a second monoclonal antibody was added to each well and then was incubated for 2 hours at room temperature. The samples were washed again and $200 \mu 1$ of substrate was added and incubated for 30 minutes at room temperature in the dark. The absorbance of the product was measured at $490 \mathrm{~nm}$. The detection threshold of the serum TNF- $\alpha$ levels was $1.9 \mathrm{pg} / \mathrm{ml}$. Based on the receiver operating characteristic (ROC) curves for the serum TNF- $\alpha$ levels, a threshold of $6.5 \mathrm{pg} / \mathrm{ml}$ was chosen as the upper limit of the normal values.

The serum levels of CEA were determined by a radioimmunoassay (CEA Roche $Z$ gel kit, Roche Tokyo, Japan), originally developed by Thomson et al. ${ }^{13)}$. The upper normal limit was set st $2.5 \mathrm{ng} / \mathrm{ml}$ based on the findings of previous reports. The sensitivity of the test was $0.5 \mathrm{ng} / \mathrm{ml}$. For the measurement of serum SCCA, a double-antibody radioimmunoassay kit was used (SCC RIA BEAD, Dainabot Co, Tokyo Japan). An upper limit of $2.0 \mathrm{ng} / \mathrm{ml}$ was considered to be normal ${ }^{14)}$. The sensitivity of the test was $0.7 \mathrm{ng} / \mathrm{ml}$. For the quantitative assay of IAP in the sera, single radial immunodiffusion, as described by Mancini et al..$^{15)}$, was employed while using commercially available agarose plates. These plates, which contain rabbit anti-IAP, were purchased from the Kayaku Antibiotics Research Co. (Tokyo, Japan). An upper limit of $500 \mu \mathrm{g} / \mathrm{ml}$ was considered to be normal ${ }^{16)}$.

The data are summarized as the mean activity (A) $[\mathrm{A} \pm \mathrm{SD}$. A statistical analysis was done using the arithmetric mean along with Student's t-test and the chi-square test. The survival rates were calculated according to the method of Kaplan-Meier, while the statistical difference was calculated by the log-rank test. A value of $\mathrm{p}<0.05$ was considered to be statistically significant.

\section{Results}

I . Comparison of the serum $\mathrm{TNF}-\alpha$ levels among $\mathrm{O}-\mathrm{SCC}$ and the healthy controls

The mean serum concentrations of the $\mathrm{TNF}-\alpha$ levels were significantly higher in the untreated patients with $\mathrm{O}-\mathrm{SCC}$ than those with the healthy controls $(\mathrm{p}<0.01)$. With $9.5 \mathrm{pg} /$ $\mathrm{ml}$ as the upper normal limit, 26 of the 38 untreated patients (68.4\%) were thus found to have elevated serum levels of $\mathrm{O}-\mathrm{SCC}$ (Fig. 1, Table 1).

II. Relationship between the serum TNF- $\alpha$ levels and the clinical parameters.

The mean serum $\mathrm{TNF}-\alpha$ levels at each $\mathrm{T}$ classification stage was $8.27 \pm 5.15 \mathrm{pg} / \mathrm{ml}$ in $\mathrm{T} 1$ ( $\mathrm{n}$ 


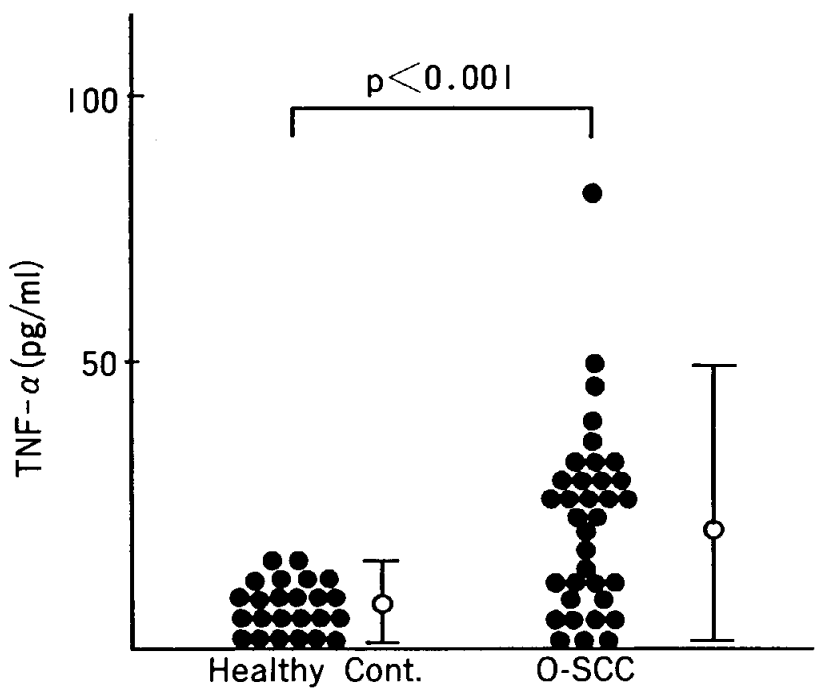

Fig. 1 Serum levels of TNF- $\alpha$ in patients with oral squamous cell carcinoma (O-SCC) and healthy controls.

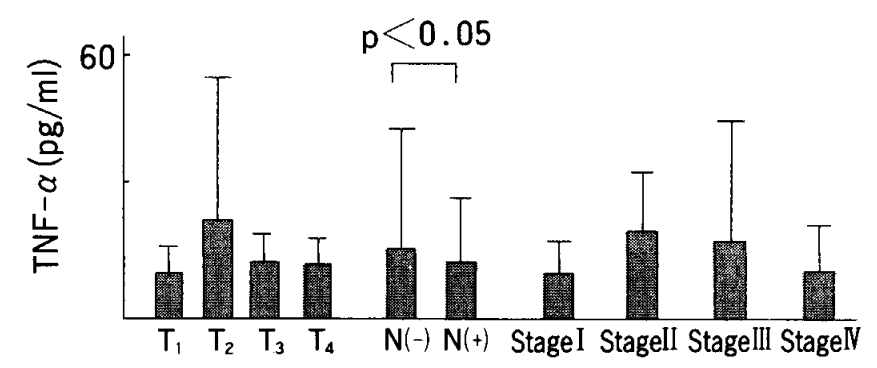

Fig. 2 Relationship between serum $\mathrm{TNF}-\alpha$ levels and clinical parameters.
Table 1 Positive rates of serum TNF- $\alpha$ level in patients with oral squamous cell carcinoma (O-SCC) and healthy controls

(\%)

\begin{tabular}{l|r}
\hline & Positive rate \\
\hline O-SCC & $68.4(26 / 38)$ \\
Healthy controls & $7.7(2 / 26)$ \\
\hline \multicolumn{2}{l|}{() Cases }
\end{tabular}

Table 2 Relationship between positive rates of serum $\mathrm{TNF}-\alpha$ and clinical parameters

\begin{tabular}{|c|c|}
\hline & Positive rate \\
\hline $\mathrm{T} 1$ & $55.6(5 / 9)$ \\
\hline $\mathrm{T} 2$ & $72.7(8 / 11)$ \\
\hline $\mathrm{T} 3$ & $71.4(5 / 7)$ \\
\hline $\mathrm{T} 4$ & $72.7(8 / 11)$ \\
\hline$N(-)$ & $76.9(20 / 26)$ \\
\hline $\mathrm{N}(+)$ & $58.3(7 / 12)$ \\
\hline Stage I & $50.0(4 / 8)$ \\
\hline Stage II & $77.8(7 / 9)$ \\
\hline Stage III & $75.0(6 / 8)$ \\
\hline Stage IV & $69.2(9 / 13)$ \\
\hline
\end{tabular}

$=9), 23.03 \pm 21.36 \mathrm{pg} / \mathrm{ml}$ in $\mathrm{T} 2(\mathrm{n}=11), 10.51 \pm 6.96 \mathrm{pg} / \mathrm{ml}$ in $\mathrm{T} 3(\mathrm{n}=7)$, and $10.60 \pm 4.13 \mathrm{pg} / \mathrm{ml}$ in T4 $(n=11)$, with no significant difference between them related to tumor size. In addition, the patients who demonstrated metastatic lymph nodes (N1 or N2) exhibited lower serum $\mathrm{TNF}-\alpha$ levels $(11.12 \pm 9.07 \mathrm{pg} / \mathrm{ml}, \mathrm{n}=12)$ than the patients without any metastatic lymph nodes (N0: $15.81 \pm 19.49 \mathrm{pg} / \mathrm{ml}, \mathrm{n}=26)(\mathrm{p}<0.05)$. When the $\mathrm{TNF}-\alpha$ level was analyzed according to UICC staging system ${ }^{13)}$, no significant differences were observed between each stage (Fig. 2, Table 2).

III. Relationship between serum $\mathrm{TNF}-\alpha$ levels and the prognosis

The mean serum concentrations of the TNF- $\alpha$ levels were significantly higher in the goodprognosis group $(16.73 \pm 18.64 \mathrm{pg} / \mathrm{ml}, \mathrm{n}=16)$ than in the poor-prognosis group $(9.62 \pm$ $5.92 \mathrm{pg} / \mathrm{ml}, \mathrm{n}=22)(\mathrm{p}<0.05)$ (Fig. 3, Table 3). The mean serum concentration of the TNF$\alpha$ levels was significantly lower in post-treatment than in pre-treatment (Fig. 4). The 5-year survival rate of the $\mathrm{TNF}-\alpha$-positive group was higher than that in the $\mathrm{TNF}-\alpha$-negative group, and a significant difference was observed between the 2 groups $(\mathrm{p}<0.05)$ (Fig. 5). As 


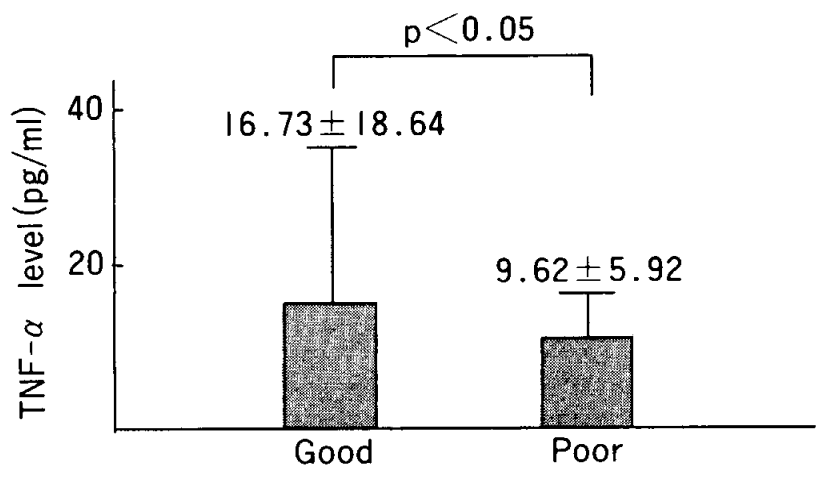

Fig. 3 Relationship between serum $\mathrm{TNF}-\alpha$ levels and prognosis.

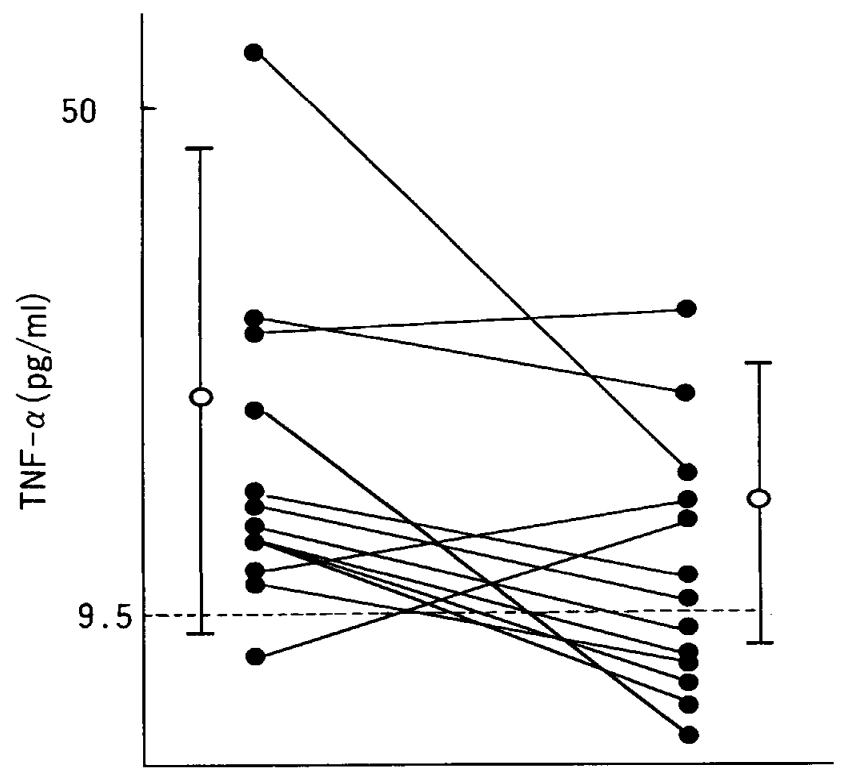

Pre-treatment Post-treatment (3M)

Fig. 4 Change in TNF- $\alpha$ levels after primary treatment $(n=13)$.
Table 3 Relationship between positive rates of serum TNF- $\alpha$ and prognosis

(\%)

\begin{tabular}{l|r}
\hline Prognosis & Positive rate \\
\hline Good & $87.5(14 / 16)$ \\
Poor & $50.0(11 / 22)$ \\
\hline \multicolumn{2}{l}{ ( ) Cases }
\end{tabular}

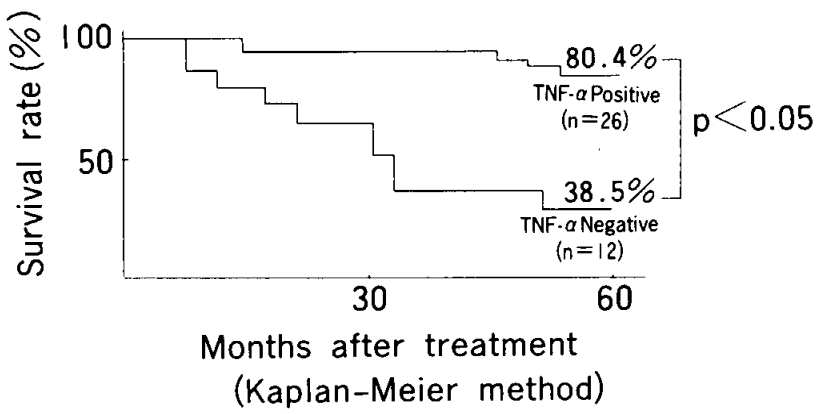

Fig. 5 Overall actuarial survival cuves by serum TNF- $\alpha$.

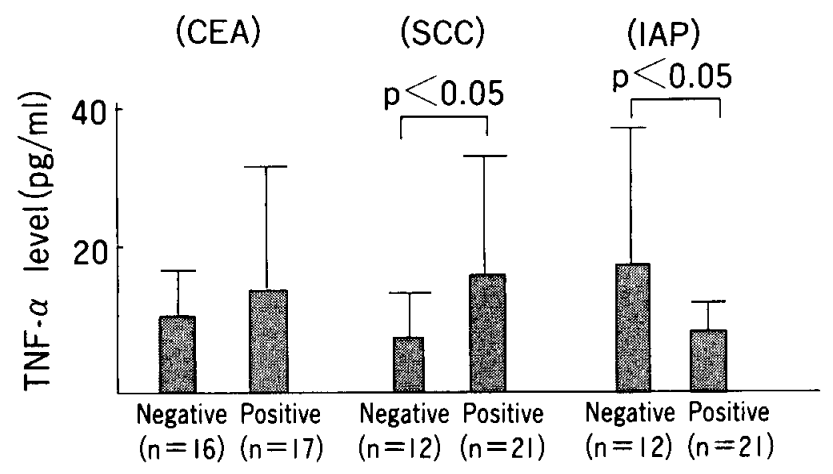

Fig. 6 Comparison of TNF- $\alpha$ levels between tumor markers-positive and negative oral cancer patients.

a result, the survival curve according to the Kaplan-Meier method revealed a better prognosis for the serum TNF- $\alpha$-positive patients than for the serum TNF- $\alpha$-negative patients.

IV. Relationship between the serum TNF- $\alpha$ levels and the tumor markers (CEA, SCCA and IAP).

The relationship between the serum $\mathrm{TNF}-\alpha$ levels and the tumor markers is shown in Fig. 6. Although no significant difference was seen between the CEA-negative group and the CEA-positive group regarding the serum $\mathrm{TNF}-\alpha$ levels, the serum $\mathrm{TNF}-\alpha$ levels in the 
SCCA-negative group were significantly lower than those in the SCCA-positive group ( $p<$ 0.05). The serum TNF- $\alpha$ levels in the IAP-negative group were also significantly higher than those in the IAP-positive group $(\mathrm{p}<0.05)$.

\section{Discussion}

$\mathrm{TNF}-\alpha$ is a polypeptide cytokaine produced by stimulated macrophages and lymphocytes ${ }^{1)}$. It was initially thought to be useful as an anticancer drug, free of any side effects but was later shown to be identical with cachectin, and is now known to have a variety of biological activities $^{17)}$ Its biologic effects include the destruction of tumor cells both in vitro and in $v_{i v o}{ }^{18)}$, endotoxin-induced shock $^{19}$, the suppression of lipoprotein lipase activity in preadipocytes ${ }^{20)}$, the stimulation of collagenase activity and prostaglandin E2 production by synovial cells ${ }^{21}$, an enhanced proliferation of fibroblasts in vitro ${ }^{22)}$, the stimulation of bone resorption ${ }^{23)}$, and stimulation of interleukin-1 production ${ }^{24)}$.

In cancer patients, high serum $\mathrm{TNF}-\alpha$ levels were recently shown to correlate with the severity of diseases ${ }^{25}$. In addition, the serum $\mathrm{TNF}-\alpha$ levels were reported to be a prognostic value in human colorectal cancer ${ }^{26)}$. In our study, the mean serum $\mathrm{TNF}-\alpha$ levels in the patients with untreated O-SCC were thus significantly higher than those in the healthy controls. In addition, the positive rate for serum $\mathrm{TNF}-\alpha$ among patients with $\mathrm{O}-\mathrm{SCC}$ was significantly higher than those in healthy controls. From these results, we thus consider the serum TNF- $\alpha$ level to be of diagnostic value in $\mathrm{O}-\mathrm{SCC}$.

The patients with $\mathrm{O}-\mathrm{SCC}$ were grouped according to $\mathrm{T}$ classification $\mathrm{N}$ classification, clinical stage, and pathologic parameters in order to examine the relationship between the serum TNF- $\alpha$ levels and each of these factors. The mean serum TNF- $\alpha$ levels in the T2 group and stage $I I$ group were significantly higher than those in other groups. In addition, the patients who present with a high level of serum TNF- $\alpha$ should probably undergo a careful examination for regional lymph node metastasis. These data thus suggest that the serum TNF- $\alpha$ levels might thus be useful as a potential marker of tumor extension in $\mathrm{O}-\mathrm{SCC}$.

The relationship between the clinical course and the serum TNF- $\alpha$ levels was examined in the patients with $\mathrm{O}-\mathrm{SCC}$. The mean serum concentrations of the TNF- $\alpha$ levels were significantly higher in the good prognosis group than in the poor prognosis group. As a result, patients with a poor prognosis often had advanced O-SCC at the time of diagnosis. Moreover, $\mathrm{TNF}-\alpha$-negative $\mathrm{O}-\mathrm{SCC}$ patients were also found to have a significantly shorter overall survival than TNF- $\alpha$-positive $\mathrm{O}-\mathrm{SCC}$ patients These findings thus show the use of the serum TNF- $\alpha$ levels to be an independent prognostic marker of $\mathrm{O}-\mathrm{SCC}$.

The usefulness of CEA, SCCA, IAP, and the combination assay of these tumor markers in $\mathrm{O}-\mathrm{SCC}$ are now accepted as a valuable tool for diagnosis, especially regarding prognosis and treatment monitoring ${ }^{57,11)}$. In the present study, we investigated the relationships between the serum TNF- $\alpha$ levels and these tumor markers. Although no significant difference was observed between the CEA-negative group and the CEA-positive group regarding the serum TNF- $\alpha$ levels, the serum TNF- $\alpha$ levels in the SCCA-negative group were significantly lower 
than those in the SCCA-positive group. On the other hand, the serum TNF- $\alpha$ levels in the IAP-negative group were significantly higher than those in the IAP-positive group. These results thus suggest that not only these tumor markers, but also the serum TNF- $\alpha$ levels, may be useful for the screening of patients with $\mathrm{O}-\mathrm{SCC}$. Moreover, the serum TNF- $\alpha$ levels also appear to be affected by the ability of the tumor-bearing host to produce TNF- $\alpha$ and the activation of the immune system.

In conclusion, determining the serum $\mathrm{TNF}-\alpha$ levels is therefore considered to be a clinically reliable and useful method for diagnosing the prognosis and also for monitoring the treatment of $\mathrm{O}-\mathrm{SCC}$ patients.

\section{Summary}

We evaluated the usefulness of the serum $\mathrm{TNF}-\alpha$ levels of 38 patients with oral squamous cell carcinoma and the relationships among the serum TNF- $\alpha$ levels and these tumor markers.

The mean serum concentration of $\mathrm{TNF}-\alpha$ for the patients with $\mathrm{O}-\mathrm{SCC}$ was significantly higher than that in the healthy controls. The mean serum concentrations of $\mathrm{TNF}-\alpha$ were also significantly higher in the good-prognosis group than in the poor-prognosis group. The survival curve revealed a better prognosis for the serum $\mathrm{TNF}-\alpha$-positive patients than for the serum TNF- $\alpha$-negative patients. A significant correlation was thus observed in the serum TNF- $\alpha$ levels and two tumor markers (SCCA, IAP).

An evaluation of the serum TNF- $\alpha$ levels in $\mathrm{O}-\mathrm{SCC}$ patients is thus considered to be a valuable tumor marker for the diagnosis and prognosis of $\mathrm{O}-\mathrm{SCC}$ patients.

\section{References}

1) Socher, S. H., Martinez, D., Craig, J. B., Kuhn, J. G. and Ollif, A.: Tumor necrosis factor not detectable in patients with clinical cancer cachexia. J. Nat. Cancer Inst. 80:595-598, 1988.

2) Philips, R. and Epstein, L. B.: Tumor necrosis factor as immunomodulator and mediator of monocyte cytotoxicity induced by itself, $\alpha$-interferon and interleukin-4. Nature 323:86-89, 1986.

3 ) Watanabe, N., Umetsu, T., Sone, H., Neda, H., Yamauchi, N., Umeno, H., Maeda, M. and Niitsu, Y.: Stimulation of antitumorigenic cytotoxicity in macrophages by tumor necrosis factor. Cancer J. 2 : 165-168, 1988.

4 ) Takeda, K., Iwamoto, S., Sugimoto, H., Takuma, T., Kawatani, N., Noda, M., Masaki, A., Morise, H., Arimura, H. and Konno, K.: Identity of differentiation inducing factors and tumor necrosis factors. Nature 323: 338-340, 1986.

5 ) Silverman, N. A., Alexander, J. C. and Chretien, P. B.: CEA levels in head and neck cancer. Cancer 37 : 2204-2209, 1976.

6 ) Kurokawa, H., Tsuru, S., Okada, M., Nakamura, T. and Kajiyama, M. : Evaluation of tumor markers in patients with squamous cell carcinoma in the oral cavity. Int. J. Oral Maxillofac. Surg. 22: 35-38, 1993.

7) Fischbach, N., Meyer, T. and Barthel, K.: Squamous cell carcinoma antigen in the diagnosis and treatment follow-up of oral and facial squamous cell carcinoma. Cancer 65: 1321-1326, 1990.

8 ) Kobayashi, Y., Amagasa, T. and Fujii, E.: Evaluation of plasma Glutathione S-Transferase- $\pi$ $(\mathrm{GST}-\pi)$ as a tumor marker for oral squamous cell carcinoma. Int. J. Clin. Oncol. 1: 44-49, 1996.

9 ) Urada, M. and Komatsu, M.: Serum dipeptidyl peptidase activities as a possible marker of oral 
cancer. Cancer $64: 1274-1277,1989$.

10) Doweck, I., Barak, M. and Greenberg, E.: Cyfra 21-1. A new potential tumor marker for squamous cell carcinoma of head and neck. Arch. Otolaryngol. Head-Neck Surg. 121 : 177-181, 1995.

11) Kurokawa, H., Yamashita, Y., Tokudome, S. and Kajiyama, M.: Combination assay for tumor markers in oral squamous cell carcinoma. J. Maxillofac. Surg. 55: 964-966, 1997.

12) Hermanek, P. and Sobin, L. H.: UICC International Union Against Cancer. TNM Classification and Grading of Malignant Tumors. Berlin, Springer-Verlag, 1987, 27-39.

13) Thomson, D. M. P. and Krupey, J.: The radioimmunoassay of circulating carcinoembryonic antigen of the human digestive system. Proc. Natl. Acad. Sci. USA 64: 16-19, 1969.

14) Meiyer, W., Eiermann, W. and Stieber, P.: Experiences with SCC antigen, a new tumor marker for cervical carcinoma. Eur. J. Cancer Clin. Oncol. 25 : 235-238, 1989.

15) Mancini G: Immunochemical quantitation of antigens by single radio immunodiffusion. Immuno. Chem. 2 : 235-239, 1965.

16) Vincenz, K., Schoenthal, E. and Zekert, F.: Diagnosis of head and neck carcinomas by means of immunological tumor markers. J. Cranio-Maxillo. Fac. Surg. 15 : 270-281, 1987.

17) Tracy, K. J., Vlassara, H., and Cerami, A.: Cachectin/tumor necrosis factor. Lancet 8647: 1122-1126, 1989.

18) Sugarman, B. J., Aggarwal, B. B., Hass, P., Palladino, M. A. and Shepard, H. M.: Recombinant human tumor necrosis factor alpha; effects on proliferation of normal and transformed cell in vitro. Science $230: 943-945,1985$.

19) Tracy, K. J. and Beutler, B.: Shock and tissue injury induced recombinant human cachectin. Science 234 : 470-474, 1986.

20) Kawakami, M. and Cerami, A.: Studies of endotoxin-induced decrease in lipoprotein lipase activity. J. Exp. Med. $154: 631-635,1981$.

21) Dayer, J. M., Beutler, B. and Cerami, A. : Cachectin/tumor necrosis factor stimulates collagenase and prostaglandin E2 production by human synovial cells and dermal fibroblasts. J. Exp. Med. 162: 2163-2166, 1985.

22) Vilcek, J., Palombella, V. J., Henriksen, D., Swenson, C., Feinman, R., Hirai, M. and Tsujimoto, M.: Fibroblast growth enhancing activity of tumor necrosis factor and its relationship to other polypeptide growth factor. J. Exp. Med. 163: 632-643, 1986.

23) Bertoloni, D. R., Nedwin, G. E., Bringman, T. S., Smith, D. D. and Mundy, G. R.: Stimulation of bone resorption and inhibition of bone formation in vitro by human tumor necrosis factors. Nature 319 : 516-518, 1986.

24) Dinarello, C. A., Cannon, J. G., Wolf, S. M., Bernheim, H. A., Beutler, B., Cerami, A., Figari, I. S., Palladino, M. A. and Connor, J. V.: Tumor necrosis factor (cachectin) is an endogenous pyrogen and induces production of interleukin 1. J. Exp. Med. 163: 1433-1450, 1986.

25) Calandra, T., Baumgartner, J. D., Grau,. GE., Wu, M. M., Lambert, P. H., Schellekens, J., Verhoef, J. and Glauser, M. P.: Prognostic values of tumor necrosis factor/cachectin, interleukin-1, interferon $-\alpha$, and interferon $-\gamma$ in the serum of patients with septic shoch. J. Infect. Dis. 161: $982-987$, 1990.

26) Satomi, A., Murakami, S., Hashimoto, T., Okamura, U., Okubo, K., Takahashi, S., Hirayama, R., Sonoda, M. and Komada, T.: Estimation of serum tumor necrosis factor- $\alpha$ and tumor tissue superoxide dismutase (SOD) activity in the prognosis of human colorectal cancer. Int. J. Clin. Oncol. 2 : 15-20, 1997. 


\title{
血清 TNF- $\alpha$ は口腔扁平上皮癌患者における
}

\section{有用な腫瘍マーカーである}

\author{
黒川 英 雄 - 山下善 弘 - 村田朋之 \\ 暒山稔
}

九州歯科大学口腔外科学第 2 講座(主任：梶山 稔教授)

私たちは，口胠扁平上皮癌 38 例における血清 $\mathrm{TNF}-\alpha$ を測定しそその有用性を検討した。

口腔扁平上皮癌患者の血清 TNF- $\alpha$ の測定值は健常成 人よりあ有意に高い值を示していた。 また，予後不良例 に比へ，予後良好例では有意に高い值を示し， 5 年生存 率でも血清 TNF- $\alpha$ 陽性例が有意に高い成績を示してい
た。さらに，血清 $\mathrm{TNF}-\alpha$ は Squamous cell carcinoma antigen (SCCA), Immunosuppressive acidic protein (IAP) の腫瘍マーカーと相関していた.

以上の研究成績から, 口腔扁平上皮癌において, 血清 $\mathrm{TNF}-\alpha$ は重要な予後因子であるとともに, 腫瘍マー カーとして臨床的に意義あるものと考えられた。 